\title{
On Entanglement of Fact and Value in the Views of Hilary Putnam
}

\author{
Ewa Rosiak-Zięba \\ https://orcid.org/0000-0001-9090-7308
}

The subject of this paper is the analysis of Hilary Putnam's thesis on the fact/value entanglement along with some of his arguments meant to corroborate this stance. One of his main objectives of putting forward this thesis is reconciliation of science and values, bringing an end to the picture of the former as a 'value-free zone'. While Putnam's polemics with standpoints conflicted with his own one are carried out in quite a comprehensive way, the way he formulates some of his constructive arguments meant to augment his own stance are a bit enigmatic. The goal of this paper is to clarify some of them. The first part of this paper briefly outlines Putnam's arguments aiming to undermine the fact/value dichotomy, which is contradictory to the thesis title. The second one is focused on the issue of so called 'thick concepts', which might be considered as counterexamples for the aforementioned dichotomy, and the thesis, correlated with the title one, that description and evaluation are interdependent.

Keywords: Putnam, fact, value, entanglement, dichotomy

The thesis title is most conveniently explained in terms of undermining the so-called "fact/value dichotomy", which involves, roughly speaking, juxtaposition of factual judgements and value judgements*. This opposition is

EWA ROSIAK-ZIĘBA, PhD, assistant professor, Warsaw School of Economics; address for correspondence: Szkoła Główna Handlowa w Warszawie, al. Niepodległości 162, PL 02-554 Warszawa; e-mail: ersieba@gmail.com

This paper was prepared within the statutory research at the Unit of Philosophy of the Warsaw 
correlated with a belief that reality can only be described by means of judgements of the former kind. It is assumed that controversies over facts can be conclusively resolved, since parties involved might refer to intersubjectively verifiable data (even if this is only possible in the longer run). This approach, however, is impossible in the case of value judgements, because they do not belong to the sphere of facts. As is often assumed by proponents of the aforementioned dichotomy, this kind of judgements can merely express a subject's emotions, attitudes or preferences. As such, they remain outside the scope of rational discussion which aims at establishing truth about reality ${ }^{1}$. The opposition between judgements about facts and judgements about values is of the utmost importance when differentiating between ethics and science, where the latter is understood as a "value-free zone". Putnam rejects the fact/value dichotomy, the conviction (based on it) that science is value-neutral, and a position that ethics should be excluded from the scope of rational discourse ${ }^{2}$. This philosopher's own stance regarding the aforementioned issue can be presented as follows: although a distinction between facts and values is plausible, there are no dualistic assumptions behind them. Classes of descriptive judgements and value judgements are not strongly disjunctive for, according to him, there are judgements which fall under both constituent parts of the dichotomy (i.e. they can be used in both descriptive and evaluative functions). This thesis is described by Putnam as "the entanglement of fact and value"3. This paper aims to clarify the thesis title and to analyse selected arguments used by the philosopher to augment it. The first part outlines his arguments meant to undermine the aforementioned dichotomy, the second is focused on the issue of so-called "thick concepts", which might be considered as

School of Economics in 2016 (KES/S16/06/16) and in 2017 (KES/S17/06/17). The working version was presented at the conference "Kryzys wartości?" (Crisis of Values?) held by UMCS between 9-10 of November 2017 in Lublin (Poland).

${ }^{1}$ H. Putnam, Reason, Truth and History, 14 ed. unchanged, Cambridge University Press, p. 127128; id., For ethics and economics without the dichotomies, [in:] H. Putnam, V. Walsch (eds.), The End of Value-Free Economics, Routledge 2011, p. 111-112, 115-116; id., Wiele twarzy realizmu, [in:] id., Wiele twarzy realizmu $i$ inne eseje, transl. by A. Grobler, PWN, Warszawa 1998, p. 397-398, 408 (The Many Faces of Realism, [in:] id., The Many Faces of Realism, Open Court Publishing Company, La Salle, Illinois, 1987); id., The Collapse of the Flact/Value Dichotomy and Other Essays, Harvard University Press, Cambridge, Massachusetts and London, England 2002, p. 28-29.

${ }^{2}$ Id., The Collapse..., op. cit., p. 17, 19.

${ }^{3}$ Id., For ethics..., op. cit., p. 112, 114; id., The Collapse..., op. cit., p. 9-13, 19; id., Reason..., op. cit., p. 135, 145. 
a shared element for both classes of judgements, and a correlated thesis on the interdependence of the description and evaluation processes.

One of Putnam's most common lines of argumentation aimed at challenging the fact/value dichotomy is based on objections to the concepts that are in fact responsible for its popularity. In his opinion, the opposition under discussion is entrenched in David Hume's famous law, that is a thesis that one cannot make claims about what ought to be on the basis of statements about what is (is-ought problem $)^{4}$. The strongest impetus for its crystallisation and popularisation, however, as Putnam indicates, was the verifiability theory of meaning formulated by the Vienna Circle 5 . One of implications of this quite radical stance, is that ethical statements - since they cannot be confirmed nor refuted on the grounds of experience $^{6}$ - might only seem meaningful, if at all. Adoption of such an approach leads to three important conclusions. To begin with, it is entrenched in a belief that the descriptive and evaluative components of our cognition can always be separated from one another, which is the premise of the fact/value dichotomy. Secondly, if one believes that ethical statements are not subject to intersubjective verification based on experience, one should assume that if they express anything at all, they refer only to that which belongs to the inner life of the subject. This emotive theory of ethics can therefore be used as an argument in favour of separating ethics from science ${ }^{7}$. Thirdly, this approach also allows us to explain why it is easier to settle contentious issues related to facts than those related to values. Putnam presents various arguments in order to challenge this concept, but he focuses mainly on the proposals put forward by Rudolf Carnap (during the first period of the Vienna Circle), while disregarding or barely mentioning the evolution of the views of Vienna Circle members (especially when it comes to the dispute over protocol statements), or differences of opinion among the members, without whom support for the dichotomy would have lost its clarity

${ }^{4}$ D. Hume, A Treatise of Human Nature, Oxford University Press, Oxford 1978, p. 469-470; H. Putnam, The Collapse..., op. cit., p. 14, 28.

${ }^{5}$ H. Putnam, For ethics..., op. cit., p. 113.

${ }^{6}$ For more detail on the verification theory of meaning see i.a. L. Kołakowski, Filozofia pozytywistyczna. Od Hume’a do Koła Wiedeńskiego, PWN, Warszawa 2003, p. 187-193; J. Kotarbińska, Ewolucja Koła Wiedeńskiego, [in:] id., Z zagadnień teorii nauki i teorii języka, PWN, Warszawa, 1990, p. 107-108, 115-122.

${ }^{7}$ See H. Putnam, Reason..., op. cit., p. 181-184, 206; id., Cóż.., op. cit., p. 493; id., For ethics..., op. cit., p. 15. 
(mention should be made in particular of Otto Neurath). The same is true of the beliefs of Willard Van Orman Quine. Putnam notes the role played by criticism of the traditional notion of the analytic-synthetic distinction, as well as a holistic approach to questioning the dichotomy between facts and values, postulated in Two Dogmas of Empiricism ${ }^{8}$. However, at the same time, he ignores the fact that Quine advocates separation of ethics from science in one of his later essays, since the former has nothing in common with the realm of facts - at least not to the extent that the latter requires ${ }^{9}$. Such a strategy might, in turn, result in generating a rather unpleasant impression that Putnam chooses historical arguments selectively to fit his earlier adopted thesis.

The point of departure for the discussion of the dichotomy is the very differentiation between factual judgements and value judgements. This distinction raises no objections from Putnam. In his opinion it is only trivial to state that there are significant differences between description and evaluation. He points out that, unlike in the case of dichotomy, regular differences have a limited scope of application. The fact that they cannot always be applied raises no controversies ${ }^{10}$. However, in the light on his analysis of the history of the development of this dichotomy carried out in The Collapse of the Fact/Value Dichotomy and Other Essays, Putnam comes to the conclusion that this differentiation was transformed into a metaphysical thesis, which (after John Dewey) might be described as "dualism". The latter is based on the assumption that ethical judgements do not apply to the facts ${ }^{11}$. The essence of this transformation is best explained in the light

${ }^{8}$ Id., The Collapse..., op. cit., p. 12-13; id., For ethics..., op. cit., p. 113-114. See also W. O. Quine, Dwa dogmaty empiryzmu, [in:] id., $Z$ punktu widzenia logiki, transl. by B. Stanosz, Fundacja Aletheia, Warszawa 2000, pp. 49-75 (Two Dogmas of Empiricism, "Philosophical Review" 1952, 60).

${ }^{9}$ W. O. Quine, O naturze wartości moralnych, [in:] id., Granice wiedzy i inne eseje filozoficzne, transl. by B. Stanosz, PIW, Warszawa 1986, p. 172-175 (On the Nature of Moral Values, [in:] A. J. Goldman, J. Kim (eds.), Values and Moral, Reidel Publ. Co., Dordrecht, Holland 1978). It is noteworthy that the Quinean concept of naturalised ethics presented in this paper at some point might partly support the thesis of entanglement of fact and value, since he introduces the idea that our ability of evaluation at the most basic form is an element of our biological equipment (Ibidem, pp. 163-165). I deal with this ethical concept in one of my papers (Quine'a koncepcja etyki znaturalizowanej, [in:] J. Nowotniak (ed.), Konteksty wartości, OW SGH, Warszawa 2016, pp. 77-97). For a discussion on Quinean ethics see i.a. O. Flanagan, Quinean Ethics, "Ethics" 1982, vol. 93, no. 1, s. 56-74; R. Gibson, Flanagan on Quinean Ethics, "Ethics" 1988, vol. 98, no. 3, pp. 534-540; R. Feleppa, Quine, Davidson and the Naturalization of metaethics, "Dialectica" 2001, vol. 55, no. 2, pp. 145-166.

${ }^{10}$ H. Putnam, For ethics..., op. cit., p. 111; id., The Collapse..., op. cit., p. 11.

${ }^{11}$ Id., The Collapse..., op. cit., p. 9, 19, 60-61. 
of the analysis of another well-known dichotomy, which seems to be related to the former - a well-known opposition between the analytic propositions and the synthetic ones. The former is traditionally explained as being true only by virtue of the rules of a given language (e.g. All bachelors are unmarried), whereas the latter's epistemic value is determined on the basis of empirical evidence (e.g. Roosters crow at sunrise). Putnam emphasises that the turning point in moving from the simple distinction to the dichotomy ("dualism") was questioning of the possibility of the existence of Kantian a priori synthetic judgements, which would be difficult to clearly attribute to one of the opposite elements ${ }^{12}$. It seems that, according to Putnam, in the course of evolution, distinction between factual and value judgements has been enriched by a thesis that these are two disjoint classes. His assertion about the entanglement of fact and value is postulated based on the negation of this very thesis.

In his essay For Ethics and Economics without the Dichotomies, Putnam argues that one of the sources of problems related to the fact/value dichotomy in (i.a.) economics is misconception of both constituent parts ${ }^{13}$. This train of thought can also be found in earlier publications by this author. For instance, Putnam notes in Reason, Truth and History that when facts and values are treated separately, far too often facts are expressed in physicalist terms or in a sort of "bureaucratic jargon", whereas values are expressed in the most abstract moral terms such as good or bad ${ }^{4}$. According to Putnam, this narrows down both concepts. Let us look at some of issues related to facts. Advocates of the aforementioned dichotomy quite frequently quote the observation that within science dealing with facts the consent is more likely to be reached than within ethics. This might be called, after Putnam, an argument from noncontroversiality ${ }^{15}$. It is often put forward along with the belief that a fact might be considered as a correlate corresponding to sensory perceptions, and that such correlates might be established by a scientific method - most preferably one of the natural sciences ${ }^{16}$. First of all, Putnam argues that, on the grounds of such a characteristic of science, not only ethics but certain other scientific disciplines

\footnotetext{
${ }^{12}$ Ibid., p. 7, 11-14.

${ }^{13}$ Id., For ethics..., op. cit., p. 116.

${ }^{14}$ Id., Reason..., op. cit., p. 139; id., The Collapse..., op. cit., p. 40; id., For ethics..., op. cit., p. 115.

${ }^{15}$ Id., Wiele..., op. cit., p. 397.

${ }^{16}$ Ibid., p. 397-398; id., For ethics..., op. cit., p. 114-115.
} 
should perhaps be excluded from the scope of rational discourse. For instance, history does not meet all the requirements of science as described above ${ }^{17}$. This leads to the conclusion that accepting this characteristic of science might result in "throwing the baby out with the bathwater". This is not the only problem that this standpoint involves, though. According to Putnam, the key issue is the link between the notion of fact and the category of sensory experience typical of the tradition of empiricism represented both by Hume's concepts and those of the Vienna Circle. Such an approach obviously promotes broadly understood observable phenomena in scientific discourse. Yet, with the ongoing revolution in science in the first half of the twentieth century, terms referring not only to observable but also unobservable entities (e.g. elementary particles or curved space-time) began to emerge in natural sciences ${ }^{18}$. The notion of fact is thus understood too narrowly within the concept, which has served as a basis for the classical form of the dichotomy under discussion. This reservation is primarily of historical nature, related to the "original sin" of the criticised concept. As to the aforementioned scientific method, Putnam indicates that methodological apparatus and scientific theories change together with scientific progress, therefore it is hard to hold an expectation that there should be one scientific method $^{19}$, regarded as a way to work out conclusive verdicts over controversies. Since such a belief is correlated with the non-controversiality argument, the latter seems to involve not only too narrow a concept of a fact, but also a bit of an idealised picture of scientific methods.

In Putnam's opinion if one holds that a certain stance is justified it merely signifies he believes it. Justification, then, is a normative idea for that belief, an idea without which it would be hard to speak of science at all. Consequently, the very notion of fact should be explained as a certain idealisation of what it is reasonable to believe in ${ }^{20}$. Science, as Putnam puts it, simply "presupposes epistemic values"21. The latter, then, play an important role in the process of establishing facts ${ }^{22}$. This argument refers to the second vector of attack on the dichotomy in question

\footnotetext{
${ }^{17}$ Id., Wiele..., op. cit., p. 400-402, 409, 412.

${ }^{18}$ Id., The Collapse.., op. cit., p. 21-24; id., For ethics..., op. cit., p. 113-114.

${ }^{19}$ Id., Wiele..., op. cit., p. 398-400, 409-410; id., The Collapse..., op. cit., p. 21-24.

${ }^{20}$ Id., Reason..., op. cit., p. 136, 201.

${ }^{21}$ Id., The Collapse..., op. cit., p. 30.

${ }^{22}$ Ibid., p. 30-33.
} 
- namely the concept of a value. First of all, Putnam points out that non-ethical value judgements are omitted in the discussion, in particular those relating to the epistemic values, such as, among others, the notion of rational acceptability, justification, consistency, and functional simplicity ${ }^{23}$. If it is assumed that value judgements are merely the expression of preferences, that should also apply to epistemic evaluations. Consequently, they should be eradicated from the scientific discourse as well as moral ones ${ }^{24}$. Although science is being dubbed as a "valuefree zone" in general, the aforementioned postulate is, nevertheless, not put forward. In Putnam's opinion this implies that the real target of the dichotomy in question are moral values alone ${ }^{25}$. Secondly, he observes that within this picture of science moral values are usually considered as so-called "thin ethical concepts", used merely for evaluative purposes, such as good or bad. Putnam believes that such an approach to ethical concepts is too narrow. Apart from thin ethical concepts, he argues, there are also thick ones, such as cruel, considerate, or selfrespect. The latter, roughly speaking, are terms that can be used both to evaluate and to describe objects or phenomena. As such, they can therefore be members of both classes: value judgements and factual judgements ${ }^{26}$. The thesis about the existence of thick concepts obviously undermines the dichotomy between facts and values in favour of their entanglement.

The source of inspiration for Putnam at this point are, i.a., the works of Iris Murdoch, or John McDowell ${ }^{27}$. The problem is that his idea of a thick concept is a bit enigmatic. Putnam admits that there is a difference between the descriptive and the evaluative use of the notion. He also agrees that some terms can only fulfil the latter function. He adds, still, that some evaluative terms can also be used for descriptive purposes ${ }^{28}$. Let us look at two sentences:

(1) The cruelties of the regime provoked a number of rebellions, and

(2) He is cruel.

${ }^{23}$ Id., Reason..., op. cit., p. 128-135; id., The Collapse.., op. cit., p.19.

${ }^{24}$ Id., Cóź po filozofie?, [in:] id., Wiele twarzy realizmu i inne eseje, PWN, Warszawa 1998, p. 493 (Why is a Philosopher, [in:] id., Realism with a Human Face, Harvard University Press, Cambridge, Massachusetts 1990).

${ }^{25}$ Id., The Collapse..., op. cit., p. 19.

${ }^{26}$ Id., Reason..., op. cit., p. 138-141, id., The Collapse..., op. cit., p. 34-35; id., For ethics..., op. cit., p. 113.

${ }^{27}$ Id., The Collapse..., op. cit., p. 38, 40; id., For ethics..., op. cit., p. 112.

${ }^{28}$ Id., The Collapse..., op. cit., p. 34-35; id, Reason..., op. cit., p. 138-139, 210. 
There is a certain description that follows from (1), says Putnam, although the scope of the evaluative term cruelty depends on the interpretative method, which will be discussed below. Let us assume that (1) was used by a historian to describe the history of a totalitarian state. The word cruelty which appears in the sentence is used descriptively, as Putnam states, since it describes the causes of certain events ${ }^{29}$. Let us now assume that (2) is the answer to the question: What kind of person is your teacher? The answer implies an evaluation of this individual both as a teacher and a person ${ }^{30}$ (at least in the first place). The difference between (1) and (2) stems from the fact that the term cruel can fulfil both a descriptive and an evaluative function. According to Putnam, however, the possibility of combining these functions does not result from the fact that such concepts contain easily separable components responsible for these functions. In The Collapse of the Fact/Value Dichotomy and Other Essays he contests the idea of thick concepts as factorable into purely descriptive and evaluative components, while the latter is to be interpreted in a non-cognitive way - using categories of attitudes or emotions (views that he ascribes to R. M. Hare and John Mackie) ${ }^{31}$. According to Putnam, evaluative and descriptive components cannot be isolated within a thick concept. This thesis, formulated by John McDowell, is known in the literature on the subject under the somewhat misleading name of disentangling argument. In fact, Putnam refers directly to this line of argumentation ${ }^{32}$. He agrees with McDowell that an attempt to isolate a purely descriptive component of a thick concept which would be independent of the evaluative counterpart is doomed to fail. Reducing a thick concept to merely a description of corresponding facts, without assuming a certain evaluative perspective, as Putnam argues, would mean that it would be difficult to make more subtle distinctions, e.g. between bravery and foolhardiness ${ }^{33}$. Instead, he promotes the position that evaluation and description are interdependent ${ }^{34}$, which will be discussed below.

${ }^{29}$ Id., For ethics..., op. cit., p. 115-116.

${ }^{30}$ Id., The Collapse..., op. cit., p. 34.

${ }^{31}$ Ibid., p. 35-43.

${ }^{32}$ Ibid., p. 38-39. For more profound analysis of the disentangling argument see i.a. D. Roberts, Shapelessness and the Thick, "Ethics" 2011, Vol. 121, No. 3 (April), s. 489-520; http://www.jstor.org/stable/10.1086/658898 [retrieved: 30.09.2017].

${ }^{33}$ Id., For ethics..., op. cit., p. 112.

${ }^{34}$ Id., The Collapse..., op. cit., p. 38, 62; see also id., Odpowiedź Gary'emu Ebbsowi, [in:] id., Wiele twarzy realizmu i inne eseje, op. cit., p. 503 (Reply to Gary Ebbs, "Philosophical Topics" 1992, Vol. 20, 
The issue of interpretation of thick terms needs to be expanded, though. Cruelty, as Putnam points out, can only be understood as inflicting unnecessary physical pain or, more broadly, causing moral suffering out of malice ${ }^{35}$. The class of events which can be cited by a historian as regards (1) can change depending on the how the term cruelty is interpreted. It can be said that thick concepts, unlike e.g. concepts such as a photon, are often regarded as vague expressions. Although it is possible to identify a certain set of properties which can be expected from the referents of such a term (by virtue of its meaning), its denotation is fuzzy. Furthermore, the class of these properties is not fully determined (since it depends on the interpretation of the term), though not necessarily to the same extent. On the other hand, some parts of the above characteristics can also be true of thin ethical concepts, whose content can likewise depend on interpretation - which is shown, for example, by the variety of definitions of the notion of good and evil offered by different ethical theories. The vagueness of both types of concepts can result from content that is not defined precisely.

Putnam notes that thick concepts generally have an emotional undertone. This does not mean that these notions can be reduced to expressions of attitudes or emotions (as postulated by researchers referring to the tradition of emotivism). In contrast to notions such as a hydrogen atom or a flatiron, terms such as cruel carry a certain emotional - negative or positive - charge. However, the same can be said about thin ethical terms such as bad or $\operatorname{good}^{36}$. The relationship between these two types of ethical notions, that is thick and thin terms, in Putnam's concept seems then a bit complicated. He suggests, for example, that in the case of saying (2) one does not have to add that we are dealing with a bad teacher and a bad person. Although it is possible to formulate a sentence like He is a very good teacher when he displays no cruelty, as Putnam adds, it is difficult to expect understanding from an interlocutor if we were to utter: He is a cruel person and a good man without introducing additional information about when he shows cruelty and when he shows goodness ${ }^{37}$. It seems that, according to Putnam, the use of the term a cruel person simply implies the notion of a bad person, at least in the sense that without additional explanations it is impossible to accept the expression

No. 1, The Philosophy of Hilary Putnam. Replies).

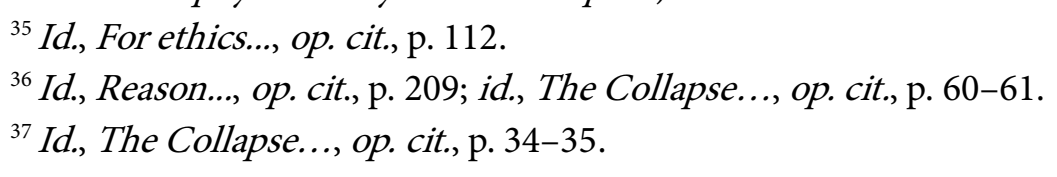


with the use of the former and at the same time reject the expression with the use of the latter with reference to the same object. These remarks suggest that some thick concepts might be correlated with certain thin ones having - let us add an appropriate emotional charge.

These observations, however, do not exhaust the issue of the relationship between thick and thin concepts. Putnam believes that, typically, in the case of the former, the user is required to be able to recognise and adopt the evaluative point of view. According to him, even descriptive uses of this type of term depend on the adoption of a certain evaluative perspective ${ }^{38}$. It is easy to notice, still, that thin ethical concepts should also require the adoption of the evaluative point of view. Therefore, it seems that this property constitutes a necessary but insufficient condition for being a thick concept. Although at first glance it may seem that thin concepts are extremely abstract and relatively more general in their nature than thick concepts, nevertheless both types have a lot in common. So, what is the difference between them? One of the examples used by Putnam to explain thin concepts is as follows:

(3) Wife-beating is wrong.

First of all, the term wrong used in (3) fulfils no descriptive function. Secondly, according to Putnam (3) represents "a universal moral condemnation" 39 . It appears that thin concepts such as wrong can be evaluative in their nature in the sense that certain precepts or (as in the case of (3)) prohibitions are correlated with them, whereas thick ones, apart from such evaluation, involve to a certain extent a description of a given phenomenon. The problem is that based on these assumptions, it is difficult to determine the boundary between these two types of concepts, since, according to Putnam, the descriptive and evaluative components cannot be told apart in the case of thick concepts, and evaluation and description are said to be interdependent. In order to explain this, we should refer to the notion of the evaluative perspective mentioned earlier. First of all, as it was explained earlier, it should be understood broadly - as encompassing not only ethical value judgements but also those of a non-ethical nature, such as epistemic value judgements. Secondly, as Putnam points out, terms such as coherent might "stand for a property of a thing that it applies to" ${ }^{40}$. At least some epistemic

\footnotetext{
${ }^{38}$ Ibid., p. 37-40, 62.

${ }^{39}$ Id., For ethics..., op. cit., p. 116.

${ }^{40}$ Id., Reason..., op. cit., p. 135.
} 
evaluative terms, then, might be used for descriptive purposes, not only the evaluative one - just as thick moral terms. Thirdly, it is noteworthy that, according to Putnam, even establishing facts (factual statements) requires the adoption of this perspective ${ }^{41}$. Such a stance appears in different forms in a number of his publications, for example in Reason, Truth and History, where he introduces his idea of thick concepts ${ }^{42}$. It seems that in this work it might be entrenched in internal realism then proclaimed by the philosopher. According to this stance, generally speaking, although reality exists independently of our epistemic states, disparate but equally accurate descriptions of it are possible. The differences between the latter derive from differences in the systems of our cognitive needs and preferences. Concepts can be interpreted in a substantially different way within individual perspectives. However, as Putnam argues, we can talk about the detection of facts within these different ways of thinking. The thesis on the existence of such systems is the so-called thesis on "conceptual relativity". The author notes in the above-mentioned book that we create both facts and values, not completely freely, though, but within a given perspective ${ }^{43}$. It seems that the thesis on the interdependency of descriptive statements and the adoption of the evaluative perspective could be interpreted against the backdrop of the above concept. If we were to agree with this, then clearly the boundary between the counterparts of the dichotomy between facts and values becomes blurred. The problem is that Putnam distances himself from the concept of internal realism together with the evolution of his views. On the other hand, in Ethics without Ontology (2004) Putnam defends the thesis about conceptual relativity ${ }^{44}$, which would constitute a coherent, albeit perhaps controversial (given the clear relativistic implications), justification of the philosophical underpinning of the thesis under discussion. However, Putnam does not mention this thesis in his later writings which tackle the issue of the entanglement of fact and value - at least explicite.

${ }^{41}$ Ibid., p. 201-203.

${ }^{42}$ Ibid., p. 127-139.

${ }^{43}$ Id., Wiele..., op. cit., p. 416-419. This concept seems to be an attempt to combine some of the conditions of metaphysical realism with some form of cognitive relativism. However, a more detailed discussion of this issue would require a separate paper.

${ }^{44}$ Id., Ethics without Ontology, Harvard University Press, Cambridge, Massachusetts and London, England 2004, p. 33-51. 
What seems promising, with regards to the issue of evaluation that could determine the interdependency between evaluation and description, are standards of rationality involved in investigation of facts. As has already been pointed out, according to Putnam the concept of fact is an idealisation of that which should rationally be believed in. In this sense, every case of fact-finding entails the involvement of epistemic evaluation. This applies both to thick concepts in ethics such as cruel or brave and to descriptive concepts such as a photon or a hydrogen atom. This interpretation, if it is right, might explain why Putnam maintains that it is impossible to isolate a descriptive component from a thick ethical concept (and not only ethical) that would be free from any evaluative admixture. We may further conclude that it is difficult to speak of pure descriptions with no evaluative constituent in them. Consequently, it turns out that the difference between descriptive and evaluative concepts, including the difference between thick and thin concepts (when it comes to evaluative concepts) is limited to the difference in terms of this admixture measured on a certain scale ${ }^{45}$. The extreme ends on this scale would correspond to thin evaluative concepts that fulfil a minimal descriptive function, and descriptive concepts that fulfil a minimal evaluative function, although their use is related to certain evaluations. Thick terms would be located in between the two ends of the scale. If we accept such an interpretation, it would be in line with Putnam's position that the distinction between factual and value judgements makes sense as long as they are not treated as disjoint classes. Consequently, though, we would come to the conclusion that these are epistemic values, that determine the interdependence between description and evaluation, not moral ones. If this is so, then the remedy for the split between science and ethics lies in epistemic evaluation, and it is the latter that should, in fact, be the reason to reject the idea of the "value-free zone" that puts moral issues aside.

One of the goals Putnam pursues when he argues in favour of the entanglement of fact and value is to undermine popular opinions about such a picture of science. He also challenges the opinion that ethics should be excluded from the field of rational discourse. In support of the thesis under discussion, Putnam undertakes polemics with concepts that contribute to the development of

${ }^{45}$ In this respect, I agree with Edward Harcourt and Alan Thomas, who claim that the difference between thin and thick concepts boils down to a location on a given scale (see E. Harcourt, A. Thomas, Thick Concepts, Analysis, and Reductionism, [in:] S. Kirchin (ed.), Thick Concepts, Oxford University Press, Oxford 2013). 
such opinions. He also questions the argument from non-controversiality, which is often raised by the proponents of the separation of science and ethics. Putnam points to the undesirable consequences that stem from maintaining the dichotomy between facts and values, which would result in the exclusion of epistemic values from the field of rational discourse, if we were to understand this dichotomy literally. He also mentions the argument related to thick concepts, which are an example of notions that can appear in both descriptive and evaluative judgements. The problem is that although the objective pursued by Putnam, i.e. reconciliation of science and values, is noble, the line of argumentation is not entirely satisfactory. This is partly due to historical arguments which are used quite selectively. The key problem is, however, that thick concepts are explained by Putnam in a rather enigmatic way. Moreover, if the reconstruction proposed above is correct, then it turns out that epistemic notions that are not controversial, rather than ethical concepts, serve as the basis for evaluation, which is meant to determine the entanglement of fact and value. Consequently, the thesis about the entanglement of fact and value does not seem as well-grounded as one would expect given all the objectives mentioned above. Despite certain shortcomings, the virtue of this concept lies in the demonstration of the existence of thick ethical concepts and indication of the role of epistemic evaluation in science.

\section{References}

Feleppa R., Quine, Davidson and the Naturalization of metaethics, "Dialectica" 2001, Vol. 55, No. 2, pp. 145-166.

Flanagan O.J. Jr., Quinean Ethics, “Ethics" 1982, Vol. 93, No. 1, pp. 56-74.

Gibson R.F., Flanagan on Quinean Ethics, "Ethics" 1988, Vol. 98, No. 3, pp. 534--540.

Harcourt E., Thomas A., Thick Concepts, Analysis, and Reductionism, [in:] S. Kirchin (ed.), Thick Concepts, Oxford University Press, Oxford 2013.

Hume D., A Treatise of Human Nature, Oxford University Press, Oxford 1978.

Kołakowski L., Filozofia pozytywistyczna. Od Hume’a do Koła Wiedeńskiego, PWN, Warszawa 2003.

Kotarbińska J., Ewolucja Koła Wiedeńskiego, [in:] id., Z zagadnień teorii nauki i teorii języka, PWN, Warszawa, 1990, pp. 106-127.

Putnam H., Reason, Truth and History, 14 ed. unchanged, Cambridge University Press 1998.

Putnam H., Wiele twarzy realizmu, [in:] id., Wiele twarzy realizmu $i$ inne eseje, transl. by A. Grobler, PWN, Warszawa 1998, pp. 325-430 (The Many Faces of Realism, [in:] id., The 
Many Faces of Realism, Open Court Publishing Company, La Salle, Illinois, 1987, pp. $1-91)$.

Putnam H., Cóż po filozofie?, [in:] id., Wiele twarzy realizmu i inne eseje, transl. by B, Stanosz, PWN, Warszawa 1998, pp. 475-496. (Why is a Philosopher, [in:] id., Realism with a Human Face, Harvard University Press, Cambridge, Massachusetts 1990, pp. 105-119, 329).

Putnam H., Odpowiedź Gary’emu Ebbsowi, [in:] id., Wiele twarzy realizmu i inne eseje, transl. by B. Stanosz, PWN, Warszawa 1998, pp. 497-517 (Reply to Gary Ebbs, "Philosophical Topics" 1992, Vol. 20, No. 1, The Philosophy of Hilary Putnam. Replies, pp. 347-58, 402-403).

Putnam H., The Collapse of the Fact/Value Dichotomy and Other Essays, Harvard University Press, Cambridge, Massachusetts and London, England 2002.

Putnam H., Ethics without Ontology, Harvard University Press, Cambridge, Massachusetts and London, England 2004.

Putnam H., For ethics and economics without the dichotomies, [in:] H. Putnam, V. Walsch (eds.), The End of Value-Free Economics, Routledge 2011, pp. 111-129.

Quine W. O., O naturze wartości moralnych, [in:] id., Granice wiedzy i inne eseje filozoficzne, transl. by B. Stanosz, PIW, Warszawa 1986, pp. 163-174 (On the Nature of Moral Values, [in:] A. J. Goldman, J. Kim (eds.), Values and Morals, Reidel Publ. Co., Dordrecht, Holland 1978).

Quine W. O., Dwa dogmaty empiryzmu, [in:] id., Z punktu widzenia logiki, transl. by B, Stanosz, Fundacja Aletheia, Warszawa 2000, pp. 49-75 (Two Dogmas of Empiricism, "Philosophical Review" 1952, 60, pp. 20-43).

Roberts D., Shapelessness and the Thick, „Ethics” 2011, Vol. 121, No. 3 (April), s. 489-520; http://www.jstor.org/stable/10.1086/658898 [retrieved: 30.09.2017].

Rosiak-Zięba E., Quine’a koncepcja etyki znaturalizowanej; [in:] J. Nowotniak (ed.), Konteksty wartości, OW SGH, Warszawa 2016, pp. 77-97. 


\section{Pobrane z czasopisma http://kulturaiwartosci.journals.umes.pl}

\section{Streszczenie}

\section{O splątaniu faktów i wartości w koncepcji Hilarego Putnama}

Przedmiotem artykułu jest analiza tezy Hilarego Putnama o splątaniu faktów i wartości wraz z wybranymi argumentami, jakie filozof ten formułuje gwoli jej wsparcia. Jednym z głównych celów, jakim ma ona służyć jest pogodzenie nauki z etyką, kładące kres wyobrażeniu, iż ta pierwsza jest neutralna pod względem wartości. Jakkolwiek polemiczne uwagi Putnama pod adresem stanowisk sprzecznych z tytułową tezą wydają się dość jasne, niektóre argumenty konstruktywne na rzecz jej wsparcia są nieco enigmatyczne. Celem tego artykułu jest objaśnienie tych ostatnich. W pierwszej części tekstu krótko omawiam argumenty Putnama wymierzone w dychotomię fakty - wartości, którą przeczy tytułowej tezie. W dalszej części eseju omawiam kwestię tzw. gęstych pojęć, które mogą stanowić kontrprzykłady dla wspomnianej dychotomii, oraz skorelowaną z tytułową tezę o współzależności opisu i oceny.

Słowa kluczowe: Putnam, fakt, wartość, splątanie, dychotomia

\section{Zusammenfassung}

\section{Über die Verflechtung von Fakten und Werten im Konzept von Hilary Putnam}

Der Gegenstand des Artikels ist die Analyse der These von Hilary Putnam, die die Verflechtung von Fakten und Werten behandelt. Es werden dabei ausgewählte Argumente herangeführt, die der Philosoph zu ihrem Nachweis formuliert. Eines der Hauptziele, denen die These dient, ist die Verbindung von Wissenschaft und Ethik, die ein Ende der Vorstellung setzt, dass die Wissenschaft wertneutral sei. Während Putnams polemische Bemerkungen hinsichtlich der gegensätzlichen Stellungnahmen klar scheinen, sind manche konstruktiven Argumente, die sie unterstützen sollen, eher enigmatisch. Der Artikel setzt sich zum Ziel, diese Argumente zu erklären. Im ersten Teil des Artikels bespreche ich kurz die gegen die Dichotomie Fakten - Werte gerichteten Argumente von Putnam, die gegen die im Titel aufgestellte These sprechen. Im weiteren Teil bespreche ich die Frage der sog. dichten Begriffe, die Gegenbeispiele für die erwähnte Dichotomie bilden können, um anschließend die mit der Hauptthese verbundene These von der Interdependenz der Beschreibung und der Bewertung zu erläutern.

Schlüsselworte: Putnam, Fakt, Wert, Verflechtung, Dichotomie 
Informacje o Autorze:

EWA ROSIAK-ZIĘBA, doktor, adiunkt, Szkoła Główna Handlowa w Warszawie; adres do korespondencji: al. Niepodległości 162, 02-554 Warszawa; e-mail: ersieba@gmail.com

\section{(c) $(1)(9)$}

